
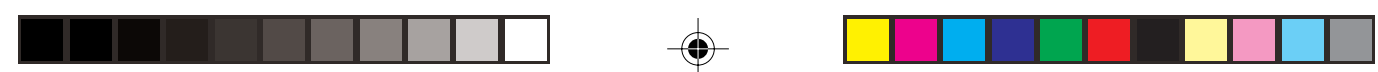

GIFF JOHNSON is editor of the Marshall Islands Journal. An American, he has lived in the Marshall Islands since 1984.

\title{
Exposing the US nuclear test legacy in the Marshall Islands
}

News Zero: The New York Times and The Bomb, by Beverly Ann Deepe Keever. Monroe, ME: Common Courage Press, 2004. 374pp. ISBN 1567511828.

$\mathrm{T}$

THE WORLD'S worst nuclear re actor accident occurred in late April 1986 at Chernobyl, in the Ukraine. Hundreds of thousands of people and millions of square miles of land were contaminated by radioactive fallout spewed from the reactor meltdown. But, in spite of great efforts by the government of the then Soviet Union to cover up and minimise the extent of this disaster, within days people and governments across Europe and, indeed, around the world were glued to their television sets or pouring over newspaper accounts of this unfolding tragedy.

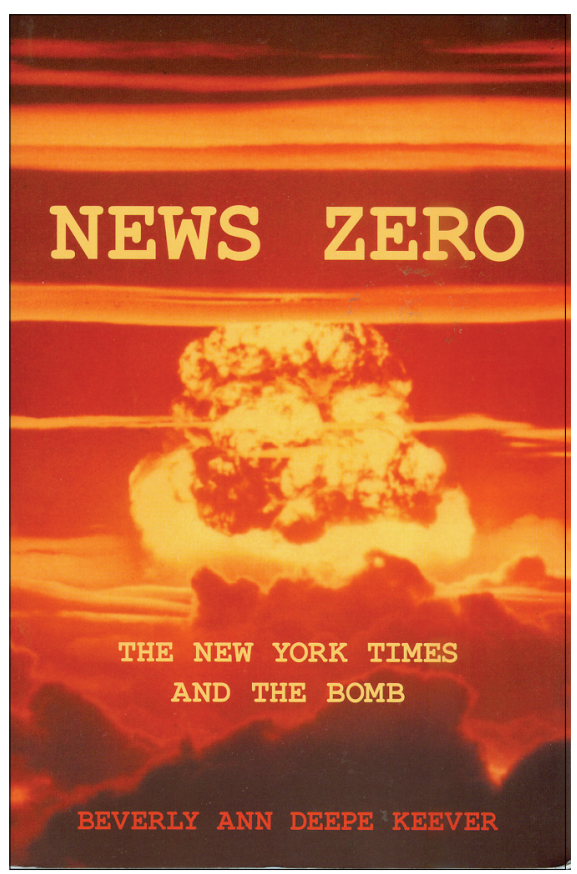

Reports today talk about a death toll in the thousands, and thyroid cancers in the tens of thousands - the majority still to come-as a result of people's exposure to radioactivity from Chernobyl.

Thirty two years earlier, the Marshall Islands experienced its own version of the Chernobyl nuclear disaster at the hands of the United States, which was using Bikini and Enewetak atolls as testing grounds for atomic and hydrogen bombs. In contrast to Chernobyl, however, the disinformation and outright lies issued by the US government in the immediate aftermath of the Bravo hy- 
drogen bomb test disaster went largely unquestioned and within days, few if any people in other parts of the world were giving much thought to the Bravo test and its consequences - consequences that continue to plague Marshall Islanders and USMarshall Islands relations.

Beverly Keever's book, News Zero, gives us particular insight into why Americans knew next to nothing about the US testing programme in the Marshall Islands or the plight of Marshall Islanders. Keever offers a detailed narrative of how The New York Times either simply ignored discussing the implications of Marshall Islands test programme nuclear fallout on health and safety, or ignored the testing in the Pacific altogether.

Eyes of Fire: The Last Voyage of the Rainbow Warrior, a recently reissued book by David Robie, offers rare insight into the day-to-day struggle of Marshall Islanders living with the effects of The Bomb - and is exactly the story that Keever says The Times failed to report on. Woven into the bigger story of the Rainbow Warrior's last voyage before French secret agents sank it in Auckland harbour is the story of the Rongelap Islanders, who were engulfed in a snowstorm of radioactive fallout from the 1954 Bravo test. It offers a number of firsthand accounts from Rongelap Island- ers about their many health problems, including stillbirths and miscarriages, after the Bravo test.

At 15 megatonnes, Bravo was the largest of the dozens of US hydrogen bombs tested in the Marshall Islands - but not the first or the last. All told, the US tested 67 nuclear weapons in the Marshall Islands from 1946 to 1958, saving its biggest and dirtiest bombs for these islands. The US detonated nearly 100 times the megatonnage at Bikini and Enewetak that it did in Nevada. In fact, the bombs exploded in the Marshall Islands during that 12-year period were equivalent to more than one Hiroshima-size bomb being set off every day.

The day of the 1954 fallout is a bittersweet memory for nuclear test victims now that they have been given some nuclear test compensation but who for most of three decades were largely ignored by the American government, except when it came time for annual medical or scientific surveys by doctors who, not having to worry about peer review, routinely placed islanders at considerable risk from ongoing radiation exposure and were prone to issue statements like Dr Robert Conard, head of the Brookhaven National Laboratory medical team, who said in a 1958 report: 'The levels of activity (on 


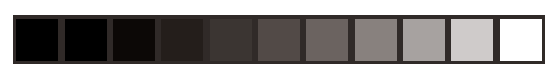

Rongelap) are higher than those found in other inhabited locations in the world. The habitation of these people on the island will afford most valuable ecological radiation data on human beings.' As Keever points out, virtually none of this was getting reported in The Times:

No evidence in the articles in The Times was discovered in this (19561958) period demonstrating that the newspaper sought more information from the US government other than it was disseminating or that it was even informing readers of what they were being kept in the dark about. Because US governmental secrecy about the yield and accurate number of tests was left unchallenged by The Times, the significant role played by the Pacific region in nuclear history was obscured by the US government until 1994 and has still not been appreciably described for Times readers. (p. 275)

But Keever also makes the point that in more recent times, news about Bikini carried in The Times was generally the lower case variety.

In the 24 years beginning in 1980 , The Times published 1539 articles containing the word bikini. But 92.3 percent of these focused on the splitlevel swimsuit and only 7.7 percent focused on Bikini Atoll or the atomic

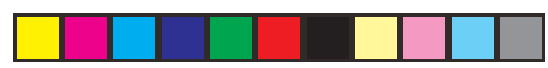

bomb there that had inspired French engineer Louis Reard to create the skimpy garb. By spotlighting Reard's 'birthday suit,' rather than the Bikini of Operations Crossroads, The Times produced, during 24 years, a mediamade view of Bikini that in a way obscured and trivialised the nuclear devastation the United States had wrought there. (p. 277)

By the 1980s, Marshall Islanders were not suffering in silence and isolation any longer. Having hired lawyers, and with the negotiations for a new political status between the U.S. and Marshall Islands governments coming to a head, they began for the first time gaining more worldwideand American government-attention to their problems. But still, says Keever, there was scant coverage of these events in The Times, including numerous US Congressional hearings that included significant testimony from Marshall Islanders about nuclear test-related issues.

Nevertheless, Rongelap Islanders were in a quandary. Despite the oftrepeated statements of condescending US government medical doctors who assured them that their health was fine and their islands were not contaminated, Rongelap Islanders intuitively knew from their own health problems that the islands they were living on and eating from were 


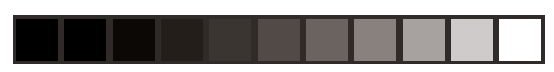

not safe for habitation. It was the fortuitous timing of the Rainbow Warrior Pacific voyage in 1985 that offered Rongelap Islanders the impetus for action. In one dramatic swoop, the self-evacuation of Rongelap put the US government on the defensive; it now had to prove that Rongelap was, in fact, safe as its officials had been claiming for years. In a 'told you so' of great misfortune, a short time later, US-funded radiological research on Rongelap confirmed Rongelap Islanders' suspicions, and in the mid-1990s, the US Congress appropriated US $\$ 45$ million for cleaning up and resettling Rongelap Island - as straight forward an admission as anyone will get from the US that it was wrong and the islanders were right.

While Robie's book does a fine job of describing the US nuclear test legacy in the Marshall Islands, Keever's point is that almost none of the significant impact from nuclear testing on the lives of Marshall Islanders has been reported by The Times. "If the Bikinians serve as "a case history of US bureaucratic incompetence and neglect", as historian-lawyer Jonathan Weisgall asserts, they also serve as a case history of the news neglect of The Times to cover the government's maladministration related to the nu-

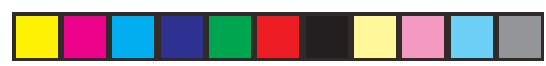

clear nomads from Bikini and Enewetak atolls,' Keever wrote:

On September 11, 2000, the Marshallese government petitioned [the US] Congress and repetitioned it two years later for more funding needed to pay for personal injury and property damages caused by the US Pacific nuclear weapons testing programme and to bolster the 'manifestly inadequate' health care programs that had been promised to monitor and care for the affected islanders. As of early 2004, Congress has taken no action. And The Times has left the story untold. (p. 260)

As of September 2006, the Congress has taken no action other than to hold two hearings on the issue. It is a story that Keever tells in great detail, and one that needs to be told over and over again for the benefit of future generations.

\section{Reference}

Robie, D. (2005). Eyes of fire: the last voyage of the Rainbow Warrior. Memorial ed. Auckland: South Pacific Books Ltd. 